ISSN : $1858-4063$

Vol. 13, No. 1, April 2017

\title{
Resiliensi Keluarga Dengan Anak Gangguan Disintegratif Melalui Konseling Kelompok
}

Festa Yumpi-R, Danan Satriyo W.

festayumpi@unmuhjember.ac.id, danansatriyo@unmuhjember.ac.id

\author{
Fakultas Psikologi, Universitas Muhammadiyah
}

\begin{abstract}
ABSTRAC
The purpose of this research was to explore how families with children with Childhood Disintegrative Disorder (CDD) who participated in group counseling that were able to move through the adverse situation that they face while raising a child with significant developmental needs and challenges. The theoretical framework that guided this research was family resilience. Qualitative research with case study approach was choosed to explore families with CDD. Observations and face-to-face interviews were conducted with each of the participants in their own home or in a school setting. The first question research focused on the experience of families who provided beneficial group counseling. Three themes emerged: a) focusing on child-positif behaviour target; b) accepting child in their ideal image realistically; c) providing motivation in positif parenting practice. The second question research focused on the experience of families who demonstrated willingness to find family resources after participated in group counseling. Four themes emerged: a) religious coping; b) positive seeking support; d) gratitude to attainable child competence.
\end{abstract}

Key words: family resilience, disintegrative disorder, group couselling, case study

\section{A. Pendahuluan}

Setiap keluarga tentu mengharapkan kehadiran anak yang cerdas dan berkembang sesuai harapan. Kenyataan menunjukkan sebagian keluarga diberi karunia anak dengan gangguan perkembangan, diantaranya adalah gangguan disintegratif. Berdasarkan PPDGJ III dan DSM V bahwa gangguan disintegratif pada anak digolongkan dalam gangguan pervasive berdasarkan. Ling et.al. (2013) dalam penelitiannya di UK menyebutkan bahwa prevalensi gangguan pervasive mengalami peningkatan rata-rata 62.6 anak setiap 10.000. Survey peneliti di lembaga asesmen psikologi anak menyebutkan bahwa ada kasus gangguan disintegrative pada anak sekitar 6 sampai 8 kasus dalam setahun. Data di lembaga asesmen tersebut terdapat 35 kasus dalam 5 
ISSN : $1858-4063$

Vol. 13, No. 1, April 2017

tahun terakhir ini (wawancara dengan tim asesmen Cahaya Nurani Resource Center, 19 Desember 2014).

Diagnosa anak dengan gangguan disintegratif ditegakkan ketika anak mengalami perkembangan yang normal sampai umur 2 tahun, kemudian diikuti kehilangan yang nyata sejumlah ketrampilan yang sudah diperoleh sebelumnya, disertai dengan kelainan kualitatif dalam fungsi sosial. Anak dapat mencapai tonggak perkembangan normal, baik fisik, emosi, sosial dan bahasa selama 2 tahun, kemudian terjadi penurunan bahkan semua kemampuan yang dicapai tersebut menghilang secara bertahap. Hal ini menyebabkan orangtua dan saudara kandung membuat perubahan dan berbagai upaya dalam menjalankan fungsi keluarga secara optimal. Harapan yang semula menginginkan anak yang berkembang normal dan ternyata memiliki anak dengan pertumbuhan dan perkembangan terhambat, tentu memberikan dampak secara emosi dan sosial bagi keluarga. Diagnosis disintegrasi terhadap anak menjadi stressor utama yang dirasakan keluarga. Keluarga juga merasakan beberapa stressor lain yang menyebabkan terjadi akumulasi dari peristiwa yang menekan. Persaingan antar saudara menjadi masalah tersendiri, orangtua memiliki agenda tersendiri untuk membagi perhatian dan waktu yang berkualitas, karena kehadiran saudara yang mengalami hambatan perkembangan menyita waktu sehingga memunculkan perilaku bermasalah bagi saudara karena merasa terisolasi. Kondisi ini juga menjadikan stress tersendiri. Penulis melakukan wawancara dengan sebuah TK inklusi mengenai program parenting yang dilakukan. Program parenting juga menghadirkan tema pola asuh bagi saudara anak yang mengalami gangguan disintegratif. Tema difokuskan pada upaya orangtua mampu meregulasi emosi dan cara merespon kebutuhan emosi anak (Reni dan Iza, komunikasi personal, 25 Februari, 2015)

Orangtua yang keduanya bekerja memiliki stress yang lebih tinggi dibandingkan dengan orangtua yang salah satunya bekerja (Mintari, 2015). Permasalahan keuangan (financial strain) menjadi beban dalam mengasuh, karena terjadi kekacauan dari aktivitas yang telah direncanakan (Research In Service of the Community, 2015). Berdasarkan wawancara penulis dengan salah satu orangtua pada Februari 2015 mengatakan bahwa orangtua harus mengatur kondisi keuangan karena ada tambahan alokasi keuangan untuk prosedur medis dan terapi bagi anak . 
ISSN : $1858-4063$

Vol. 13, No. 1, April 2017

Menurut penelitian Mintari (2015), ditemukan bahwa tingkat stres orang tua yang memiliki anak berkebutuhan khusus lebih tinggi dibandingkan dengan stres orang tua yang memiliki anak normal.

Interaksi akumulasi dari peristiwa hidup ini menyebabkan keluarga berada dalam krisis. Krisis tersebut mencakup frustasi, kecemasan, keresahan, terkejut, ketidakberdayaan, marah, kesedihan, kekesalan. Krisis ini terkat dengan ketidakmampuan keluarga dalam meregulasi emosi yang disebabkan karena menghadapi perilaku dan emosi anak yang tidak lazim sebagai akibat dari hambatan perkembangannya. Keluarga berusaha keras menemukan cara mengatasi masalah tersebut, namun tidak sedikit kegagalan yang dijumpai sehingga hal ini menambah rangkaian krisis yang melingkupi kehidupan keluarga.

Keluarga membutuhkan kemampuan untuk dapat bangkit kembali dari situasi krisis dan mampu beradaptasi dalam menjalani kehidupan. Kemampuan untuk bertahan dan bangkit dari situasi krisis ini merupakan konsep resiliensi. Resiliensi merupakan proses adaptasi secara baik dalam menghadapi kemalangan, trauma, tragedi, ancaman atau bahkan stres yang signifikan.

Resiliensi sebagai salah satu karakter positif diharapkan dapat mengatasi krisis keluarga. Resiliensi merupakan faktor protektif serta sumber internal dan eksternal untuk mengatasi stress, memecahkan konflik, dan menguasai seluruh tugas-tugas perkembangan (Dankonski dkk, 2006).

Walsh (2006) menyatakan bahwa resiliensi keluarga adalah proses adaptasi dan coping dalam keluarga sebagai sebuah unit fungsional. Resiliensi melibatkan proses dinamis yang membantu beradaptasi dalam masalah yang signifikan. Kekuatan dan sumber daya ini yang memungkinkan individu serta keluarga untuk sukses menghadapi krisis dan masalah yang persisten.

Penelitian ini berfokus pada gambaran resiliensi keluarga yang memiliki anak dengan gangguan disintegrasi melalui konseling kelompok. Konseling kelompok merupakan proses pertalian antara konselor dengan anggota kelompok yang menekankkan pada pengembangan diri (Prawitasari, 2005). Individu dapat memperoleh pengalaman belajar dari anggota yang lain. Anggota dapat belajar tentang dirinya dalam hubungannya dengan anggota keluarga yang lain. Anggota kelompok dalam konseling kelompok dapat belajar memecahkan masalah berdasarkan masukan dari anggota 
ISSN : $1858-4063$

Vol. 13, No. 1, April 2017

lainnya. Anggota kelompok dalam penelitian ini adalah orangtua yang memiliki anak dengan gangguan disintegrasi. Keluarga ini mendapat kesempatan untuk mengembangkan pemahaman, keyakinan dan perilaku yang tepat dalam konseling kelompok.

Keluarga diharapkan hadir sebagai pelindung potensial bagi anak yang mengalami gangguan disintegrasi. Kenyataan diatas menunjukkan bahwa stress yang dialami keluarga menyebabkan keberfungsiannya menjadi kurang optimal. Hal ini berdampak pada kondisi yang memperburuk tumbuh kembang anak.

Berdasarkan survey tersebut tampaknya keluarga belum dapat menangkap faktor pendukung yang berpotensi untuk membangun resiliensi, selain itu juga belum mampu menemukan kekuatan dan sumberdaya sebagai upaya untuk beradaptasi dalam menghadapi krisis sebagai perubahan yang terjadi atas kehadiran anak yang mengalami gangguan disintegrasi.

Mengingat pentingnya resiliensi dalam keluarga, maka dibutuhkan sarana untuk mengembangkan resiliensi tersebut melalui konseling kelompok, sehingga penelitian ini menjadi penting untuk mengungkap gambaran resiliensi keluarga ketika anak mereka mendapat diagnose disintegrasi. Proses resiliensi dalam konseling kelompok perlu dieksplorasi untuk mendapatkan gambaran upaya keluarga bertahan dan bangkit kembali dalam situasi krisis, serta menemukan kekuatan dan sumber daya yang berpotensi untuk melakukan adaptasi dalam situasi krisis tersebut

\section{Resiliensi Keluarga}

Konsep resiliensi keluarga berakar dari pemahaman mengenai resiliensi individu. Resiliensi merupakan proses adaptasi secara baik dalam menghadapi kemalangan, trauma, tragedi, ancaman, atau bahkan sumber stres yang signifikan. Konsep resiliensi tidak hanya mencakup kemampuan untuk bertahan tetapi juga bangkit kembali dari krisis.

Definisi resiliensi keluarga berakar dari ulasan mengenai resiliensi terhadap individu, Resiliensi keluarga (family resicilence) adalah kemampuan keluarga untuk melanjutkan hidup setelah ditimpa kemalangan atau tekanan yang berat.

Pendekatan resiliensi keluarga bertujuan untuk mengenali dan membentengi proses interaksi yang menjadi kunci bagi kemampuan keluarga untuk bertahan dan bangkit dari tantangan kehidupan yang mengganggu. 
ISSN : $1858-4063$

Vol. 13, No. 1, April 2017

Lestari (2012) menyatakan bahwa perspektif resiliensi memandang distress sebagai tantangan bagi keluarga bukan hal yang merusak, serta melihat potensi yang dimiliki keluarga untuk tumbuh dan melakukan perbaikan. Walsh mendefinisikan resiliensi sebagai kemampuan untuk bangkit kembali dari penderitaan, dengan menjadi lebih kuat dan lebih memiliki sumber daya, resiliensi lebih dari sekedar kemampuan untuk bertahan (survive), karena resiliensi memampukan orang untuk sembuh dari luka yang menyakitkan, mengendalikan kehidupannya dan melanjutkan hidupnya dengan penuh cinta dan kasih sayang.

Ada tiga faktor yang menjadi kunci bagi resiliensi keluarga, yaitu system keyakinan, pola pengorganisasian keluarga dan proses komunikasi dalam keluarga. Keyakinan merupakan lensa yang digunakan untuk memandang dunia dan kehidupan. Sistem keyakinan merupakan inti dari resiliensi keluarga yang mencakup tiga aspek, yaitu kemampuan untuk memaknai penderitaan, berpandangan positif yang melahirkan sikap optimis dan keberagaman (Lestari, 2012).

Hanekom (2008) menyatakan bahwa proses resiliensi sebagai interaksi antara faktor risiko dan faktor protektif. Faktor protektif dapat dianggap kuat, berinteraksi dengan faktor risiko, mengurangi dampak negative dari risiko. Model ini juga mengatakan bahwa resiliensi tidak hanya bangkit kembali dan menjadi kuat tetapi juga adanya kekuatan yang membantu seseorang untuk bertahan dari masalah mereka serta tumbuh menjadi manusia yang lebih kuat. Resiliensi bukanlah hal yang dibicarakan fokus pada individu saja melainkan sebuah proses interaksional antara karakteristik individual dan lingkungan. Resiliensi juga dimiliki oleh sumber daya yang lebih banyak akan lebih mudah beradaptasi dengan peristiwa kehidupan yang menekan. Keluarga yang dapat beradaptasi dengan sukses akan mencapai keseimbangan dalam keluarga. Keluarga tersebut dapat dikatakan resilien.

Keluarga yang resilien dengan memiliki anak yang mengalami hambatan perkembangan tampak dari cara keluarga menghadapi stressor dan strain, dukungan yang diterima keluarga, karaterisktik ketahanan keluarga sebagai sumber daya dan cara keluarga menilai peristiwa yang dihadapinya, serta peristiwa distress yang dirasakan keluarga.

Keluarga sebagai sebuah satu kesatuan. Blakc and Lobo (2008) mengatakan bahwa resiliensi keluarga adalah proses adaptasi dan coping dalam keluarga sebagai sebuah 
ISSN : $1858-4063$

Vol. 13, No. 1, April 2017

unit fungsional. Resiliensi melibatkan proses dinamis yang membantu beradaptasi dalam masalah yang signifikan. Kekuatan dan sumber daya ini yang memungkinkan individu serta keluarga untuk sukses menghadapi krisis dan masalah yang persisten. Kekuatan dan sumber daya yang dimiliki dapat memulihkan dan bertumbuh dari pengalaman yang tidak menyenangkan.

Konsep resiliensi keluarga tidak hanya melihat individu (anggota keluarga) sebagai sumber daya potensial, namun meluas bahwa keluarga sebagai sebuah unit fungsional. Patterson (2002) mengatakan bahwa resiliensi keluarga melibatkan potensi perubahan dan pertumbuhan baik secara personal maupun relasional yang dapat membantu keluar dari masalah. Keluarga dapat menjadi lebih kuat dan lebih pandai ketika berhadapan dengan masalah di masa yang akan datang. Adanya masalah dapat menjadi kesempatan bagi keluarga untuk menilai kembali prioritas,menstimulasi hubungan yang lebih baik dan tujuan hidup keluarga. Anggota keluarga mungkin dapat menemukan atau mengembangkan hikmah dan kemampuan baru.

\section{Gangguan Disintegratif Masa Kanak}

Gangguan disintegrasi masa kanak-kanak juga dikenal sebagai sindrom Heller. Thomas Heller adalah seorang pendidik di Austria. Ia menjelakan tentang gangguan disintegratif masa kanak-kanak tersebut sejak tahun 1908. Gangguan disintegrative adalah gangguan perkembangan pada masa kanak-kanak yang digolongkan dalam gangguan pervasive menurut Pedoman Penggolongan dan Diagnosis Gangguan Jiwa PPDGJ dan DSM V (Maslim, 2013). Charan (2012) menyatakan definisinya bahwa:

Childhood disintegrative disorder (CDD), also known as Heller's syndrome and disintegrative psychosis, is a rare condition characterized by late onset $(>3$ years of age) of developmental delays in language, social function, and motor skills.

Kelompok gangguan ini ditandai dengan kelainan kualitatif dalam interaksi social yang timbal balik dan dalam pola komunikasi, serta minat dan aktivitas yang terbatas, stereotipik, berulang. Kelainan kualitatif ini menunjukkan gambaran yang pervasive dari fungsi-fungsi individu dalam semua situasi, meskipun dapat berbeda dalam derajat keparahannya.

Diagnosa ditegakkan berdasarkan suatu perkembangan normal yang jelas sampai usia minimal 2-3 tahun, yang diikuti dengan kelainan yang nyata dari ketrampilan yang 
ISSN : $1858-4063$

Vol. 13, No. 1, April 2017

sudah diperoleh sebelumnya, disertai dengan kelainan kualitatif dalam fungsi-fungsi sosial. Ling et.al (2013) mengatakan:

Childhood disintegrative disorder (CDD) is under the catogary of pervasive developmental disorder and is characterized by the behavioral, cognitive, language regression between 2 and 10 years after entirely normal early development.

Definisi Ling tersebut diperkuat oleh Charan (2012) dalam case report sebagai berikut; seorang anak perempuan berusia 10 tahun datang dengan keluhan anak sering marah dan sulit komunikasi. Anak mencapai perkembangan normal sampai usia 5 tahun. Perkawinan kedua orangtuanya masih ada hubungan kerabat. Ia lahir normal, tidak ada infeksi dan tidak ada komplikasi setelah kelahiran anak. Anak mencapai tonggak perkembangan yang normal baik dari aspek kognitif, bahasa, motorik, emosi dan social hingga umur 5 tahun. Anak juga dapat melakukan toilet training, mampu mengendalikan buang air besar dan buang air kecil. Anak juga bersekolah dan belajar membaca puisi dan cerita. Dia bisa mandi di bawah pengawasan. Pada usia 4 tahun anak anak mendapat infeksi saluran pernapasan, kemudian ia demam dan batuk selama 6 bulan. Sejak itu anak berhenti sekolah dan mulai kehilangan semua tonggak komunikatif.

\section{Penyebab Gangguan Disintegratif Masa Kanak-Kanak}

Kebanyakan ahli sepakat bahwa ada kemungkinan secara genetik mengarah pada spektrum autisme. Teorinya adalah bahwa gen abnormal diaktifkan pada tahap awal perkembangan sebelum kelahiran, kemudian gen ini mempengaruhi gen lain yang mengkoordinasikan perkembangan otak anak, seperti resiko yang ada di lingkungan, antara lain keracunan, infeksi yang dapat menyebabkan efek tersebut.

Pemeriksaan komprehensif secara medis dan neurologis pada anak yang didiagnosis gangguan disintegrasi jarang mengungkap penyebab medis atau neurologis yang mendasarinya, diduga terjadinya epilepsy menjadi penyebab lebih tinggi pada anak dengan gangguan disintegrasi. Gangguan disintegrasi masa kanak-kanak juga telah dikaitkan dengan: 1) tuberous sclerosis, dalam kondisi ini non-kanker (jinak) tumor tumbuh di otak; 2) penyakit penyimpanan lipid, dalam kelompok ini jarang terjadi gangguan metabolisme keturunan, namun lebih disebabkan oleh penumpukan racun dari kelebihan lemak (lipid) yang terjadi di otak dan sistem syaraf; 3) sclerosing 
ISSN : $1858-4063$

Vol. 13, No. 1, April 2017

panencephalitis subakut, terjadi infeksi kronis di otak yang disebabkan oleh virus, campak sehingga terjadi radang di otak dan kematian sel-sel saraf.

\section{Konseling Kelompok}

Konseling kelompok adalah suatu proses antar pribadi yang terpusat pada pemikiran dan perilaku yang sadar dan melibatkan fungsi-fungsi terapi seperti sifat permisif, orientasi pada kenyataan, katarsis, saling mempercayai, saling memperlakukan dengan baik, saling pengertian, saling menerima dan saling mendukung. Konseling kelompok adalah sebagai suatu proses pertalian pribadi (interpersonal relationship) antara seorang atau beberapa konselor dengan sekelompok individu yang dalam proses itu konselor berupaya membantu menumbuhkan dan meningkatkan kemampuan individu untuk menghadapi dan mengatasi persoalan atau hal-hal yang menjadi kepedulian masing-masing individu melalui pengembangan pemahaman, sikap, keyakinan dan perilaku dengan cara memanfaatkan suasana kelompok (Tohirin, 2011)

Layanan konseling kelompok mengaktifkan dinamika kelompok untuk membahas berbagai hal yang berguna bagi pengembangan pribadi dan pemecahan masalah individu (Sherman dalam Corey, 2009). Konseling kelompok memberi kesempatan anggota kelompok memperoleh kemampuan untuk mengatur dirinya sendiri dan mengarahkan hidupnya sendiri, dimulai dari hubungan antar pribadi di dalam kelompok dan dilanjutkan dalam kehidupan sehari-hari di luar lingkungan kelompoknya (Latipun, 2008).

\section{B. Metodologi}

Pendekatan kualitatif dengan rancangan studi kasus dipilih untuk menguak pengalaman keluarga dalam membangun resiliensi setelah mengikuti konseling kelompok yang dilakukan oleh lembaga pendidikan sebagai program parenting. Studi kasus adalah suatu inkuiri empiris yang menyelidiki fenomena di dalam konteks kehidupan nyata, bilamana; batas-batas antara fenomena dan konteks tidak tampak dengan tegas; dan multisumber bukti dapat dimanfaatkan dalam penggalian data (Yin, 2009). Rumusan masalah penelitian ini adalah: 1) apa saja perubahan yang dilakukan keluarga dalam mengatasi krisis keluarga ketika mendapat diagnose gangguan disintgratif pada anak mereka.; 2) bagaimana keluarga tersebut menemukan kekuatan dan sumber daya untuk beradaptasi menjalani kehidupan. Unit analisis dilakukan pada 
ISSN : $1858-4063$

Vol. 13, No. 1, April 2017

pengalaman tiga keluarga melakukan perubahan dan menemukan kekuatan serta sumber daya setelah mengikuti konseling kelompok yang diselenggarakan oleh lembaga pendidikan sebagai program parenting secara berkala. Metode pengumpulan data yang dipergunakan dalam penelitian ini adalah wawancara mendalam dan observasi. Analisis dilakukan secara tematik. Subyek penelitian adalah 3 keluarga yang memiliki anak dengan diagnosa disintegratif yang telah berpartisipasi dalam group counseling. Keluarga ini telah mengikuti group counseling yang diselenggarakan oleh lembaga pendidikan sekolah Cahaya Nurani, suatu lembaga pendidikan anak usia dini yang menerima murid dengan gangguan disintgratif, autis, gangguan bahasa dan kesulitan belajar. Strategi sampling yang sesuai untuk mendeskripsikan kelompok tertentu secara mendalam ini adalah pengambilan sampel homogen. Hal ini dilakukan agar sampel sungguh-sungguh mewakili (bersifat representatif terhadap) fenomena yang dipelajari (Patton dalam Poerwandari, 2005).

\section{Hasil Penelitian}

Tema-tema yang dipaparkan dalam temuan penelitian merupakan hasil data wawancara pada setiap informan, observasi dan refleksi catatan lapangan. Tema-tema tersebut akan disajikan secara berurutan sesuai dengan kronologi berdasarkan rumusan masalah penelitian.

Pertama, penelitian ini menjawab rumusan masalah perubahan yang dilakukan keluarga setelah mengikuti konseling kelompok. dalam mengatasi krisis ketika anak mereka mendapat diagnose gangguan disintegrasi. Analisis difokuskan pada pengalaman keluarga dalam memanfaatkan pengetahuan yang diperoleh dari konseling kelompok. Konseling kelompok yang diselenggarakan sekolah Cahaya Nurani dapat dirasakan manfaatnya oleh keluarga anak berkebutuhan khusus. Hal ini sesuai dengan tujuan Sentra Anak Berkebutuhan Khusus Cahaya Nurani dalam menyelenggarakan konseling kelompok, yaitu untuk meningkatkan kemampuan orangtua dalam menghadapi dan mengatasi persoalan yang berhubungan dengan pengasuhan anak berkebutuhan khusus. Berikut ini adalah tema yang muncul:

a. Membuat target perilaku positif

Tema ini menceritakan tentang perubahan-perubahan yang dialami berdasarkan pengetahuan yang diperoleh dalam konseling kelompok. Subyek membuat 
ISSN : $1858-4063$

Vol. 13, No. 1, April 2017

definisi mengenai perilaku yang menjadi sasaran, yaitu target perilaku untuk anak dan untuk diri mereka sebagai orangtua.

(Keluarga Ad)

"Pengalaman saya waktu itu, dimana saya harus berusaha untuk melepas diapers (pampers) anak saya. Dulu saya terlena, saya pikir nunggu sampai anak saya bisa bicara, tapi dalam parenting (konseling kelompok) saya dapat penjelasan kalo bisa bantu diri itu ndak perlu nunggu bisa bicara"

Pernyataan ini menunjukkan bahwa orangtua mendapat pencerahan tentang bantu diri yang dapat diajarkan pada anak berkebutuhan khusus.

Berikut pernyataan subyek yang membuat perubahan diet makanan yang sebelumnya berpandangan bahwa diet makan membuat anak kurang gizi. Penjelasan mengenai diet makan bebas glutein dan cafein membuat orangtua yakin bahwa diet makan ini lebih berpeluang untuk meningkatkan kemampuan anak dalam regulasi emosi.

Keluarga Dv:

"Alhamdulillah sekarang sudah dilatih di Cahaya Nurani disuruh diet terus apa gitu sekarang sudah diet alhamdulillah banyak sekali penurunan emosi nya dan fokusnya sekarang juga lebih meningkat, dulu kan nggak fokus sama sekali kalo dipanggil nggak mau ini bunda, sekarang agak melihat, terus kalau disuruh, "ayo vani sepatunya taruh disini", itu mau bunda.

\section{Keluarga Nz}

Banyak hal-hal yang kita tidak tahu cara menangani masalah emosi ke anak,... tanda-tandanya seperti ini dan cara penanganannya seharusnya seperti ini.

(Wawancara dengan keluarga, Nz)

\section{Keluarga Dv}

"Alhamdulillah sekarang merespon bunda, dulunya sama sekali gak merespon kalo di panggil. Sebenarnya kan kalo ada suara-suara agak takut, seperti suara kayak mercon, sekarang udah gak takut, bunda udah gak takut, saya cobakan terus, saya tenangkan dengan sentuhan, peluk, akhirnya menjadi kebiasaan.",

b. Menerima anak dalam gambaran ideal yang realistis

Partisipasi subyek dalam konseling kelompok memberikan dampak perubahan cara pandang terhadap anak. Orangtua sudah lebih realistis dalam membuat harapan pada anak. 
ISSN : $1858-4063$

Vol. 13, No. 1, April 2017

"Anak-anak ini anak-anak hebat, anak2 kuat, saya ndak peduli sama akademiknya anak-anak yang penting bisa baca sama tulis udah, saya ndak nuntut dia sarjana, dia harus pinter harus ini ndak. Dia bisa baca Al Qur'an dan bakti sama kamu ibu nya, udah cukup, saya ndak minta anak ini jadi insinyur, nanti suatu saat kalau ndak diterima di SD ya udah kita ajarin sendiri di rumah, kamu ibunya kamu madrasahnya, jangan bingung anak lain sekolah ini ndak, ndak sekolah ndak apa-apa, yang penting bakti sama orang tua nanti kalo masalah kerjaan nanti Allah yang atur semuanya" Alhamdulillah saya udah kuat"

(Wawancara dengan keluarga, $\mathrm{Nz}$ )

c. Memunculkan semangat dalam menerapkan pengasuhan positif

Tema ini menggambarkan keluarga menemukan semangat dalam menerapkan pengasuhan positif

"kita ada titik jenuh menangani biasanya kita lagi down, dengan ikut parenting ini jadi semangat lagi, jadi selalu menantikan kalo yang parenting itu selalu menyempatkan waktu walau sibuk gitu Bunda, selalu berusaha soalnya kan selalu ingin lebih"

Kedua, temuan penelitian selanjutnya adalah menyajikan tema upaya keluarga menemukan kekuatan dan sumber daya untuk beradaptasi menjalani kehidupan ketika anak mendapat diagnose gangguan disintegrasi. Focus analisis ditujukan pada pengalaman keluarga dalam menghadapi kenyataan bahwa anak mereka mendapat diagnose gangguan disintegrasi yang mengarah pada kondisi anak berkebutuhan khusus dalam kategori autis ringan, sedang dan berat, mental retardasi ringan, sedang dan berat. Upaya keluarga dalam beradaptasi terhadap kenyataan tersebut menjadi perhatian dalam analisis, yaitu upaya memotivasi diri, menemukan pemecahan masalah, membangun harapan agar bangkit kembali dalam kondisi yang terpuruk. Temuan tema-tema adalah sebagai berikut:

a. Religious coping

Religious coping adalah cara penyelesaian masalah yang menggunakan praktek ritual ibadah dan mengunakan keyakinan yang menghubungkan dirinya dengan Tuhan dalam menyelesaikan masalah sehingga membantu individu untuk beradaptasi dalam situasi kehidupan yang menekan.

"Saya pasrahkan sama Allah, mungkin nanti anak saya bisa sembuh. Saya hanya berdoa saja, semoga tetap sehat dan bisa tumbuh seperti anak-anak lainnya" (Wawancara dengan keluarga Sf) 
ISSN : $1858-4063$

Vol. 13, No. 1, April 2017

"Sebelumnya dulu saya itu memang sholatnya bolong bolong, alhamdulillah saya dikasih ini lebih dekat sama Allah sekarang. berusaha lebih dekat kepada Allah. itu membuat saya lebih menerima sekarang. Bisa mengatasi perasaan dan membuat sabar menghadapi anak saya, karena kadang emosi atau apa."

(Wawancara dengan keluarga,Dv )

"Apapun yang disarankan sama dokternya sama psikiaternya jalani, kata keluarga "kamu itu dikasih anugerah sama Allah, kamu ndak usah susah susah, karena Allah percaya kamu itu kuat"

(Wawancara dengan keluarga, $\mathrm{Nz}$ )

"Saya bilang ke diri saya, kamu kurang syukur apa sama Allah, anak mu bisa ngomong, bisa jalan, kenapa masih menyesal? Kamu jangan lihat yang diatasatas, lihat yang dibawah bawah nya Nizam."

(Wawancara dengan keluarga, Nz 9)

"Sampe besok pagi nya suami saya nanya" kenapa kamu nangis?" Saya bilang "kenapa Allah itu kok segininya ke aku? Kenapa aku dikasih 2, satu aja belum tentu bisa, ini dikasih 2 yaapa masa depannya anak-anak ini?" Kata suami saya "kenapa kamu nangis, Allah uda nentuin gimana masa depan nya, apa yang kamu tangisi",

(Wawancara dengan keluarga, $\mathrm{Nz}$ )

b. Positive seeking support

Tema ini membahas tentang upaya keluarga menemukan sumber-sumber kekuatan dari usahanya mencari dukungan orang-orang terdekat

"Saya selalu mendekatkan sama tetangga tetangga, yaa pokoknya nggak cuek gitu loh ke tetangga. Saya kalo ada apa apa juga ngobrol gitu ke tetangga tetangga, karena anak saya seperti ini, kata tetangga saya "oh iya sabar kalo punya anak kayak gini"

"Ya saya crita ke orang-orang sekitar, karena pastilah anak saya kelihatan aneh, karena anak saya kadang kalo emosi suka jambak jambak rambutnya, jadi saya harus bilang, Alhamdulilah orang-orang ngerti"

"Hasilnya waktu itu ada indikasi autis, saya sampaikan kekeluarga, hebatnya keluarga itu bunda tidak menampakkan kecewa atau sedih"

(Wawancara dengan keluarga, Nz )

c. Mensyukuri kompetensi yang dicapai anak

Tema ini merupakan temuan cara keluarga mensyukuri kompetensi yang dicapai anak dalam tahap kemampuan anak. Keluarga menerima apa adanya sebagai bentuk rasa bersyukur. 
ISSN : $1858-4063$

Vol. 13, No. 1, April 2017

"Saya dan istri sudah ikhlas mas, yang penting anaknya sehat, semua saya pasrahkan sama Allah. Mungkin ini jalannya Syafira"

(Wawancara dengan keluarga S)

\section{Pembahasan}

Keluarga yang memiliki anak gangguan disintegrasi berupaya untuk bangkit kembali dengan melakukan perubahan untuk mengatasi krisis ketika anak mereka mendapat diagnose gangguan disintegrasi. Partisipasi keluarga dalam konseling kelompok membawa perubahan sebagai dampak dari pengetahuan dan ketrampilan yang diperoleh dalam konseling kelompok. Perubahan yang terjadi sesuai dengan kebutuhan masing-masing keluarga Masing-masing keluarga mampu menemukan dirinya dan memahami diri mereka dengan lebih baik. Berdasarkan pemahaman tersebut, keluarga rela menerima diri mereka dan lebih terbuka terhadap aspek-aspek positif kepribadiannya. Masing-masing keluarga menetapkan suatu sasaran atau target yang ingin dicapai, yang diwujudkan dalam sikap dan perilaku yang lebih konstruktif. Keluarga membuat definisi mengenai perilaku yang menjadi sasaran, yaitu target perilaku untuk anak dan untuk diri mereka sebagai orangtua. Adapun target perilaku positif yang dilakukan adalah membentuk bantu diri, diet makan, dan adaptasi terhadap masalah sensori integrasi.

Target perilaku positif ini adalah kemampuan mendasar pada anak gangguan disiintegrasi dalam semua tingkat. Kesediaan keluarga melakukan perubahan melakukan target perilaku positif ini karena dalam keluarga muncul perasaan mampu yang dijelaskan oleh Bandura tentang self-efficacy yaitu keyakinan individu untuk menjalankan perilaku untuk mendapatkan hasil yang diharapkan (Rattlte dalam Suharjana, 2007).

Menerima anak dalam gambaran ideal yang realistis merupakan tema yaitu keluarga lebih realistis dalam membuat harapan pada anak. Partisipasi subyek dalam konseling kelompok memberikan dampak perubahan cara pandang terhadap anak. Keluarga sudah lebih realistis membuat harapan pada anak. Materi di konseling kelompok memaparkan tentang asesmen anak berkebutuhan khusus. Materi ini menguraikan cara mengidentifikasi batas kemampuan yang dicapai anak dalam semua aspek, yaitu bahasa yang mencakup bicara dan pemahaman, bahasa ekspresi dan bahasa receptive, social emosional, kognitif, sensori integrasi, okupasi. Keluarga bersama 
ISSN : $1858-4063$

Vol. 13, No. 1, April 2017

terapis menyusun program individu untuk anak. Pemahaman orangtua terhadap anak dapat meningkatkan regulasi emosi pada keluarga. Temuan ini sejalan dengan penelitian Hidayati (2013) yaitu peningkatan regulasi emosi pendamping yang memiliki regulasi emosi dapat mengurangi perilaku maltreatment. Perilaku maltreatment adalah suatu kategori umum yang meliputi semua situasi dimana orangtua atau orang lain yang mestinya bertanggungjawab terhadap kesejahteraan anak melakukan kekerasan atau mengabaikan kebutuhan anak.

Menurut Walsh (2012a) resiliensi keluarga melibatkan potensi personal dan relasi transformasi dan pertumbuhan yang dapat menguatkan dalam menghadapi kemalangan. Keluarga yang resilien menyatakan mampu mengatasi masalah yang terjadi pada anaknya yang autis. Bandura menyebut percaya pada kemampuan mengatasi masalah ini adalah self efficacy (Secer, Ogelman, Onder, 2012).

Bersyukur pada keluarga yang anaknya mengalami gangguan disintegrative adalah menunjukkan emosi positif misalnya rasa senang pada apa yang dicapai anak secara individu, meskipun tidak sesuai dengan perkembangan normal. Wood, et al. (2010) menyimpulkan bahwa bersyukur berkorelsi dengan sifat-sifat yang berkaitan dengan fungsi emosi positif dan hubungan social yang positif. Orang yang bersyukur lebih mudah mengendalikan marah dan bebas dari depresi.

\section{E. Kesimpulan}

Penelitian telah mengungkap perubahan yang dilakukan keluarga setelah mengikuti konseling kelompok. dalam mengatasi krisis ketika anak mereka mendapat diagnose gangguan disintegrasi. Partisipasi subyek dalam konseling kelompok memberikan dampak perubahan cara pandang terhadap anak. Orangtua sudah lebih realistis dalam membuat harapan pada anak dan mampu menerapkan pengasuhan yang positif.

Penelitian juga dapat mengungkap upaya keluarga menemukan kekuatan dan sumber daya untuk beradaptasi menjalani kehidupan ketika anak mendapat diagnose gangguan disintegrasi. Kerangka teori resiliensi keluarga digunakan untuk mengungkap upaya keluarga bangkit kembali membangun harapan. Adapun upaya yang digunakan adalah menggunakan religious coping dengan praktek ritual ibadah dan mengunakan keyakinan yang menghubungkan dirinya dengan Tuhan dalam menyelesaikan masalah sehingga membantu individu untuk beradaptasi dalam situasi kehidupan yang menekan. 
ISSN : $1858-4063$

Vol. 13, No. 1, April 2017

Selanjutnya adalah menemukan sumber-sumber kekuatan dari usahanya mencari dukungan orang-orang terdekat. Selan itu dengan cara mensyukuri perkembangan anak

Konseling kelompok yang diselenggarakan Yayasan Cahaya Nurani memberi dampak perubahan pengetahuan dan penerapan pengasuhan yang positif. Temuan tema penelitian dapat digunakan sebagai materi parenting dalam menguatkan keluarga anak sehingga keluarga memiliki resiliensi. Peneliti yang tertarik untuk melanjutkan penelitian ini dapat menggunakan variasi subyek karena memungkinkan untuk memperkaya tema. Peneliti dapat mengembangkan konstruk resiliensi keluarga berdasarkan tema penelitian ini.

\section{DAFTAR PUSTAKA}

Charan, S.H., (2012). Journal of Pediatric Neurosciences. Jan-Apr; 7(1): 55-57. DOI: $\underline{10.4103 / 1817-1745.97627}$

Corey, G. 2009. Teori dan Praktek Konseling dan Psikoterapi. Bandung: Refika Aditama.

Dankonski, M. E., Keiley, M. K., Thomas, V., Chice, P., Lloyd, S. A., \& Seery B. L. (2006). Affect regulation and cycle of violence again women: new direction for understanding the process. J Fam Vol., 21, 327-339.

DeHaan, LG., Hawley, DR., Deal., JE. In Becvar, D.S. (ed.), 2013. Handbook of Family Resilience. 17-29. (C) Springer Science+Business Media New York : DOI 10.1007/978-1-4614-3917-2_2

Hanekom, L. 2008. Resilience in families with a child living with autism spectrum disorder. Africa: Nelson Mandela Metropolitan University.

Latipun. (2008). Psikologi Konseling. Malang : UMM Press

Ling, X. et al. 2013. The Findings of 18F-FDG PET/MRI Coregistration A Case Of Childhood Disintegrative Disorder. Journal of Nuclear Medicine. May 2013 vol. 54 no. supplement 2 2002. Diakses tanggal 8 Maret 2015 pada: http:/ /jnm. snmjournals. org/content/54/supplement_2/2002.short

Maslim, R. (2013). Buku saku Diagnose gangguan jiwa, rujukan ringkas dari PPDGJIII dan DSM 5. Jakarta. PT Nuh Jaya

Mayoclinic. 2010. Childhood Disintegrative. Di akses tanggal 27 Februari 2015 pada: http://www.mayoclinic.com/health/childhood-disintegrativedisorder/DS00801/DSECTION=coping-and-support 
ISSN : $1858-4063$

Vol. 13, No. 1, April 2017

McCubin, H,I., Thompson, A.I., \& McCubbin, M. 2001. Family Measures: Stress, Coping, and Resiliency. Hawaii: Kamehameha Schools

Mintari, T.P. 2015. Gambaran Strategi Coping Pada Orang Tua yang Memiliki Anak Berkebutuhan Khusus (ABK). Skripsi. Fakultas Psikologi Universitas Muhammadiyah. Tidak Diterbitkan

Patterson, J. (2002). Integrating Family Resilience and Family Stress Theory. Diakses tanggal 10 Februari 2013 pada: www. hbftpartnership.com/... /Integrating family_resilience_and_stress_t

Poerwandari, E. K. (2005). Pendekatan Kualitatif untuk Penelitian Perilaku Manusia. Jakarta: Lembaga Pengembangan Sarana Pengukuran dan Pendidikan Psikologi (LPSP3) Fakultas Psikologi UI

Prawitasari , J.E., 2005. Pengantar Psikoterapi Kelompok. Lokakarya Psikoterapi Kelompok. Yogyakarta. Makalah. Tidak diterbitkan.

Research In Service of the Community (2015). Children with Special Needs: The Role of the Family. Diakses pada 25 Maret di: http://wwwe.openu.ac.i1/geninfor/openletter/ol17/12-14.pdf

Secer, Z., Ogelman, H.G., Onder, A. (2012). Analysing Mothers' Self-efficacy Perception towards Parenting in Relation to Peer Relationships of 5-6 year-old Preschool Children. Educational Consultancy and Research Center. www.edam.com.tr/estp

Tohirin. 2011. Bimbingan Dan Konseling di Sekolah dan Madrasah (berbasis Integrasi). Jakarta: Rajawali Pers.

Walsh, F. (2006). Strengthening Family Resilience. Seond edition. New York: The Guilford Press.

. Wood, A. M., Froh, J.J., Geraghty, A.W.A.., (2010). Gratitude and well-being: a review and theoretical integration, Clinical Psychology Review. doi:10.1016/j.cpr.2010.03.005

Yin. 2008. Studi Kasus, Desain dan Metode (terjemahan Dr. M. Djauzi Mudzakir, MA). Jakarta: PT. Raja Grafindo Persada. 